\title{
Non-coordinate Regulation of Rhizobium Nitrogenase Synthesis by Oxygen: Studies with Bacteroids from Nodulated Lupinus angustifolius
}

\author{
By BRIAN D. SHAW \\ Plant Physiology Division, Department of Scientific and Industrial Research, Palmerston North, \\ New Zealand
}

(Received 5 March 1982; revised 21 July 1982)

\begin{abstract}
Experimental conditions which allowed liquid suspensions of lupin bacteroids (Rhizobium NZP 2257) to reduce acetylene at high rates were established. At a dissolved oxygen concentration of $2 \mu \mathrm{M}$, swirled suspensions of the bacteroids reduced acetylene at a linear rate of $23 \pm 5 \mathrm{nmol}$ (mg cell protein $)^{-1} \mathrm{~min}^{-1}$. The kinetics of protein synthesis were measured by pulse labelling with $\left[{ }^{35}\right.$ S]methionine followed by two-dimensional electrophoretic analysis of cell lysates. When the suspensions were suddenly exposed to air, the rate of synthesis of the two nitrogenase components declined differentially. The decline in the rate of synthesis of the $\mathrm{Fe}-$ protein polypeptides resembled that observed for all the nitrogenase polypeptides in Klebsiella pneumoniae (Eady et al., 1978); the rate of synthesis of the MoFe-protein polypeptides, however, showed a much slower decline. Several models are proposed to account for these results.
\end{abstract}

\section{INTRODUCTION}

In symbiosis with plants, principally legumes, Rhizobium bacteria produce a high proportion of their cellular protein as nitrogenase (Whiting \& Dilworth, 1974). Nitrogenase is an enzyme pair, consisting of a MoFe-protein and an Fe-protein. Studies of Klebsiella pneumoniae (Eady et al., 1978; Dixon et al., 1980) and Azotobacter chroococcum (Robson, 1979) cultures have shown repressive effects of both ammonium salts and oxygen on nitrogenase synthesis. In both organisms the repression of the component polypeptides was coordinate, but in $K$. pneumoniae the two $\mathrm{MoFe}$-protein polypeptides and the Fe-protein polypeptide were progressively repressed whereas in $A$. chroococcum the three polypeptides were abruptly and rapidly repressed when the oxygen pressure was raised. The synthesis of MoFe-protein by cultures of free-living Rhizobium japonicum is progressively repressed by oxygen (Scott $e$ t al., 1979) although at a slower rate than the comparable repression in $K$. pneumoniae. A series of papers (Bisseling et al., 1979, 1980a,b) detailing experiments with pea bacteroids in situ provide evidence from labelling studies and immunoassays for there being different amounts of the two nitrogenase proteins during nodule development and water stress. It therefore appeared possible that the regulation of nitrogenase proteins in rhizobia might be different from the regulation in other nitrogen-fixing bacteria. The present investigation was undertaken to examine this premise.

\section{METHODS}

Organisms. Blue lupins (Lupinus angustifolius cv. Bitter Blue) were inoculated with Rhizobium strain NZP 2257 and grown at $180 \mathrm{~W} \mathrm{~m}^{-2}$ with alternating $12 \mathrm{~h}, 25^{\circ} \mathrm{C}$ light periods, and $12 \mathrm{~h}, 20^{\circ} \mathrm{C}$ dark periods. The rhizobia were obtained from the culture collection of the Applied Biochemistry Division, Department of Scientific and Industrial Research, New Zealand, and maintained at $4{ }^{\circ} \mathrm{C}$ on agar slopes of yeast extract medium (Dalton, 1980) with regular subculturing.

Preparation of bacteroids. Oxygen-free nitrogen was used as the gas phase, and to sparge all buffers. All solutions were at $\mathrm{pH} 7 \cdot 4$, and low concentrations of sodium dithionite were used to avoid changes in the protein labelling profile which otherwise occurred, especially in the $30 \mathrm{kDal}$ region. Nodules were crushed in a screw press (Bergersen, 1966) in 0.3 M-sucrose, $50 \mathrm{~mm}$-TES/KOH buffer, $2 \mathrm{~mm}-\mathrm{MgSO}_{4}, 5 \mathrm{~mm}$-sodium dithionite, $2 \%$ (w/v) 
BSA, $4 \%(\mathrm{w} / \mathrm{v})$ polyvinylpyrrolidone. The brei was layered on a $15 \%$ to $30 \%(\mathrm{w} / \mathrm{v})$ gradient of sucrose in $50 \mathrm{mM}-$ Tris/ $\mathrm{HCl}, 2.5 \mathrm{~mm}$-sodium dithionite, overlayered with $20 \mathrm{~mm}$-sodium dithionite, and centrifuged in air at $3000 \mathrm{~g}$ for $10 \mathrm{~min}$ (modified from the aerobic method of Sutton \& Mahoney, 1977). The bacteroid zone was collected, the cells pelleted at $6000 \mathrm{~g}$ for $5 \mathrm{~min}$, and suspended in $0.3 \mathrm{M}$-sucrose, $50 \mathrm{mM}$-TES/KOH, $2 \mathrm{mM}-\mathrm{MgSO}_{4}, 2 \% \mathrm{BSA}$, at 4 $\times 10^{9}$ cells $\mathrm{ml}^{-1}$.

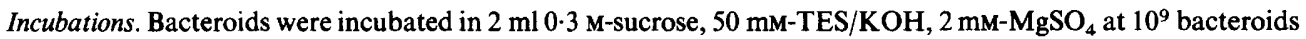
$\mathrm{ml}^{-1}$ in $100 \mathrm{ml}$ bottles with serum caps. This gave a large excess of oxygen in the gas phase. The gas phase comprised different mixtures of oxygen in nitrogen, with $10 \%(\mathrm{v} / \mathrm{v})$ acetylene (welding grade) for measurements of acetylene reduction activity. The atmospheric pressure was usually $102 \mathrm{kPa}$. The oxygen concentration was measured as $2 \mu \mathrm{M}$ by an oxygen electrode (Yellow Springs Instruments, Ohio, U.S.A.) at $24^{\circ} \mathrm{C}$ with a rotational speed of $26 \mathrm{rad} \mathrm{s}^{-1}$, a liquid area to volume ratio of $11 \cdot 1 \mathrm{~cm}^{-1}$ (the standard conditions) and with the $\mathrm{pO}_{2}$ at $0.19 \mathrm{kPa}$. The solubility of oxygen in the suspension fluid was $97 \%$ of its solubility in distilled water.

Radioactive labelling. The conditions described above were used to measure the influence of an abrupt elevation of oxygen concentration on the incorporation of $\left.{ }^{35} \mathrm{~S}\right] \mathrm{methionine}\left(51 \mathrm{TBq} \mathrm{mmol}{ }^{-1}\right.$; Amersham) into bacteroid proteins. The experimental design of Robson (1979) was used. A total of 12 bottles were set up, with $0 \cdot 2 \mathrm{kPa}$ oxygen in the gas phase. This suboptimal pressure ensured that traces of oxygen, if added during subsequent steps, would not depress nitrogenase activity. Equal portions of the bacteroid preparation were added to each bottle and after $10 \mathrm{~min}$ one bottle at a time was injected with $370 \mathrm{kBq}$ portions of degassed, nitrogen-sparged $\left.{ }^{35} \mathrm{~S}\right]$ methionine for a $10 \mathrm{~min}$ interval. Labelling was terminated by injecting chilled incubation buffer containing L-methionine (final concentration $0.5 \mathrm{mg} \mathrm{ml}^{-1}$ ), and transferring to ice. After $30 \mathrm{~min}$, seven remaining bottles were uncapped and exposed to the air, and these were labelled with $\left[{ }^{35} \mathrm{~S}\right]$ methionine for $10 \mathrm{~min}$ intervals over the next $70 \mathrm{~min}$. One bottle was kept under $0.2 \mathrm{kPa}$ oxygen for $85 \mathrm{~min}$ and then labelled with [ $\left.{ }^{35} \mathrm{~S}\right] \mathrm{methionine}$ while two others were used for assays of acetylene reduction throughout the experiment - one for assay at $0 \cdot 2 \mathrm{kPa}$ oxygen and the other to monitor the effect of air on nitrogenase activity.

Electrophoresis. Following labelling, bacteroids from incubations were pelleted at $6000 \mathrm{~g}$ for $5 \mathrm{~min}$, suspended in $20 \mu \mathrm{l} 50 \mathrm{~mm}$-Tris/ $\mathrm{HCl}, \mathrm{pH} 7.4$ and lysed by the addition of $200 \mu \mathrm{l}$ Nonidet $\mathrm{P} 40$-urea lysis solution and five cycles of freezing and thawing; portions $(20 \mu \mathrm{l})$ were then separated by two-dimensional electrophoresis using the methods of O'Farrell (1975). Pure urea (BDH, Aristar) was used. An ampholyte (LKB, Ampholine) range of pH 4-8 was chosen, to encompass the majority of the proteins. Triton X-100 was not used in place of Nonidet P40 (Roberts $e t$ $a l ., 1978)$ because it caused the Fe-protein spot to lengthen appreciably in the second dimension. The $\mathrm{pH}$ gradients were measured on $5 \mathrm{~mm}$ segments of control gels soaked in degassed $50 \mathrm{mM}-\mathrm{KCl}$ for $4 \mathrm{~h}$, and were therefore approximate. Isoelectric focusing gels were soaked in SDS-mercaptoethanol solution for 15-30 min before electrophoresis in the second dimension, to minimize the loss of protein. For the second dimension, $10 \%$ or $12 \%$ $(\mathrm{w} / \mathrm{v})$ polyacrylamide gels $0.8 \mathrm{~mm} \times 10 \mathrm{~cm}$ with a $1 \mathrm{~cm}$ stacking gel (Laemmli, 1970) were run at a constant $20 \mathrm{~mA}$, and $15 \mathrm{~V} \mathrm{~cm}^{-1}$ maximum. One-dimensional electrophoresis was done under the same conditions. Marker protein was applied to the second dimension as $50 \mu \mathrm{l}$ gels of $1 \%(\mathrm{w} / \mathrm{v})$ agarose containing native protein alone or with the urea and Nonidet P40 concentrations as used in the first dimension gels. A single brand of SDS (BDH, specially pure) was used.

Quantitation. Two independent methods were used. By one method, spots were excised from dried, stained gels. After solubilization, the radioactivity was determined by liquid scintillation counting. By the other method, autoradiographs were made of duplicate gels, and scanned by a rotating drum densitometer with digital output (Optronics International). Spot densities were summed by a PDP 11/45 computer, using local programs. There was good agreement between the two methods.

Nitrogenase purification. The methods of Whiting \& Dilworth (1974) and Bisseling et al. (1978) were used with modifications. Bacteroids $\left(10^{12}\right)$ were prepared by crushing $30 \mathrm{~g}$ of nodules in $0 \cdot 3 \mathrm{M}$-sucrose, $50 \mathrm{~mm}$-potassium phosphate, $2 \%$ polyvinylpyrrolidone, $5 \mathrm{mM}$-sodium dithionite, $\mathrm{pH} 7 \cdot 4$, followed by differential centrifugation ( 2 min at $270 \mathrm{~g}$ to remove debris, then $5 \mathrm{~min}$ at $6000 \mathrm{~g}$ to pellet the bacteroids). An initial protein fractionation was effected by osmotic shock of the bacteroids: the pellet was suspended in $4 \mathrm{M}$-glycerol, $25 \mathrm{~mm}$-Tris/ $\mathrm{HCl}, 20 \mathrm{~mm}$ -

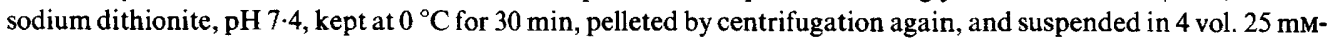
Tris $/ \mathrm{HCl}, 20 \mathrm{~mm}$-sodium dithionite, $\mathrm{pH} 7.4$ with vigorous shaking (Shah, 1980). After re-centrifugation at $6000 \mathrm{~g}$ for $5 \mathrm{~min}$ the pale brown supernatant was discarded and the pellet suspended in $3 \mathrm{ml} 50 \mathrm{mM}$-TES/KOH, $2 \mathrm{mM}$ $\mathrm{MgCl}_{2}, 0 \cdot 2 \mathrm{~mm}$-dithiothreitol, $20 \mathrm{mM}$-sodium dithionite, $\mathrm{pH} 7 \cdot 4$ (Whiting \& Dilworth, 1974). This suspension was sonicated under a stream of argon for $15 \mathrm{~min}$ at full power, then centrifuged for $30 \mathrm{~min}$ at $37000 \mathrm{~g}$. The supernatant was applied to a DEAE-cellulose column equilibrated with a basal buffer of $50 \mathrm{~mm}-\mathrm{Tris} / \mathrm{HCl}, 0 \cdot 2 \mathrm{~mm}$ dithiothreitol, $20 \mathrm{~mm}$-sodium dithionite, $\mathrm{pH} \mathrm{7.4}$. The column was washed successively with one bed volume of basal buffer, two bed volumes of $0.15 \mathrm{M}-\mathrm{NaCl}$ in basal buffer, two bed volumes of $0.28 \mathrm{M}-\mathrm{NaCl}$ in basal buffer and two bed volumes of $0.5 \mathrm{M}-\mathrm{NaCl}$ in basal buffer. MoFe-protein was eluted with the $0 \cdot 15 \mathrm{M}-\mathrm{NaCl}$ and $\mathrm{Fe}$-protein with the $0.28 \mathrm{M}-\mathrm{NaCl}$. Activity was assayed by acetylene reduction as described by Whiting \& Dilworth (1974). For further purification of MoFe-protein on Sephadex G-150, $50 \mathrm{mM}-\mathrm{MgCl}_{2}$ in basal buffer was used. At a protein 

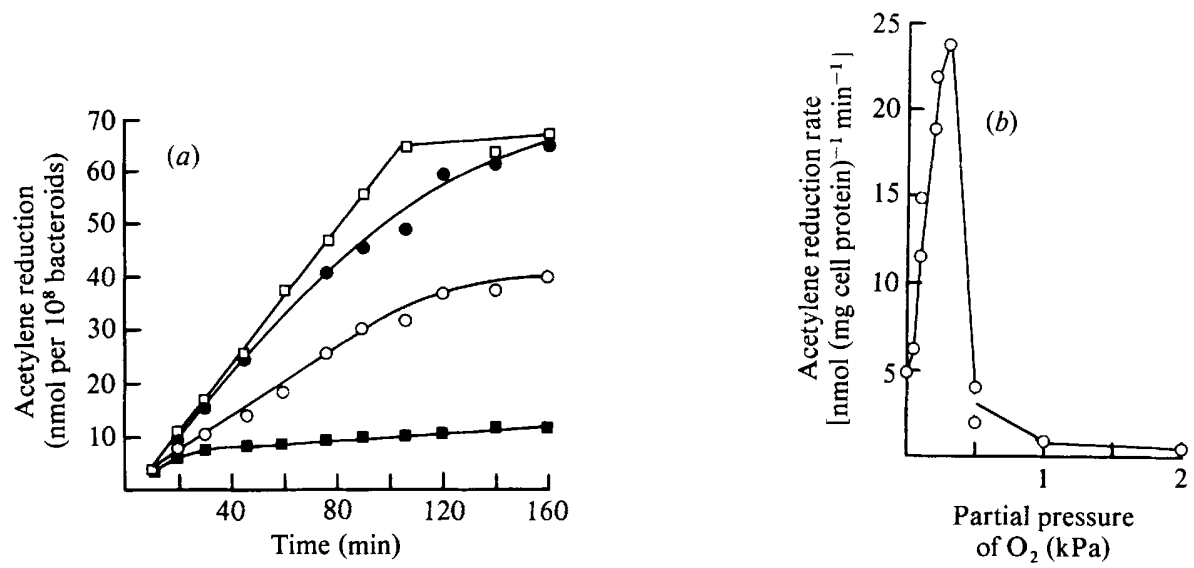

Fig. 1. (a) Time course of acetylene reduction of bacteroids at different partial pressures of oxygen in the gas phase : $0.1 \mathrm{kPa}(O) ; 0.2 \mathrm{kPa}(O) ; 0.3 \mathrm{kPa}(\square) ; 0.5 \mathrm{kPa}(\square)$. (b) Acetylene reduction as a function of the partial pressure of oxygen.

concentration of $0.9 \mathrm{mg} \mathrm{ml}^{-1}$, the specific activities of the preparations of MoFe-protein and Fe-protein were 356 and $228 \mathrm{nmol}(\mathrm{mg} \text { protein })^{-1} \mathrm{~min}^{-1}$, respectively.

Bacteroid protein content. Bacteroids were prepared isoosmotically from sucrose gradients (as above) with added mannitol. The bacteroid band was collected, syringed vigorously to remove plant membranes, and layered over a $35 \%(\mathrm{w} / \mathrm{v})$ sucrose solution (Robertson et al., 1978). After centrifugation at $6000 \mathrm{~g}$ for $10 \mathrm{~min}$, the pellet was suspended in the extraction buffer and a total cell count and Lowry protein estimate made. The protein content was $0.10 \pm 0.04 \mathrm{pg}$ per bacteroid (mean and S.E. of five measurements).

Electron microscopy. Bacteroids were pelleted and examined under the electron microscope by the methods of Robertson et al. (1978).

\section{RESULTS}

The maintenance of nitrogenase activity in bacteroid suspensions

In order to test the effects of elevated oxygen concentrations upon the synthesis of nitrogenase polypeptides, conditions allowing maximal nitrogenase activity were first established. The criterion used was ability to sustain high linear rates of acetylene reduction for several hours (Fig. 1a). This criterion was of importance to the conditions chosen because not all time courses were linear; some reached an early maximum, as in the case of supra-optimal oxygen concentrations (data not shown). Oxygen carriers could not be employed because they might have buffered the effect of oxygen changes. Stirred suspensions of bacteroids were tested for acetylene reduction at various partial pressures of oxygen in nitrogen. The oxygen optimum for strain NZP 2257 bacteroids, derived from Fig. 1(a) and additional data, is shown in Fig. $1(b)$. The maximum rate of acetylene reduction, of $23 \pm 5 \mathrm{nmol}\left(\mathrm{mg}\right.$ cell protein) ${ }^{-1} \mathrm{~min}^{-1}$, was obtained between 0.2 and $0.3 \mathrm{kPa}$ oxygen in the gas phase, i.e. $2-3 \mu \mathrm{M}$ oxygen in solution. This value compares well with other reported rates of acetylene reduction by bacteroids (Laane $e t$ al., 1978; Bergersen \& Turner, 1975). The bacteroid preparations used for the observations described here were composed of nearly equal proportions of cells possessing and lacking a peribacteroid membrane (Robertson et al., 1978), with few shrunken or distorted profiles (Fig. 2).

\section{Location of nitrogenase components on two-dimensional gels}

The elution behaviour of the two nitrogenase components purified from Rhizobium NZP 2257 differed from that described by Bisseling et al. (1978) for nitrogenase from pea bacteroids, and was more like that reported for yellow lupin bacteroids (Whiting \& Dilworth, 1974) and soybean bacteroids (Scott et al., 1979). The protein preparations were run on two-dimensional gels and a single major protein spot was observed with each protein (Fig. $3 a, b$ ). In the case of the MoFe- 


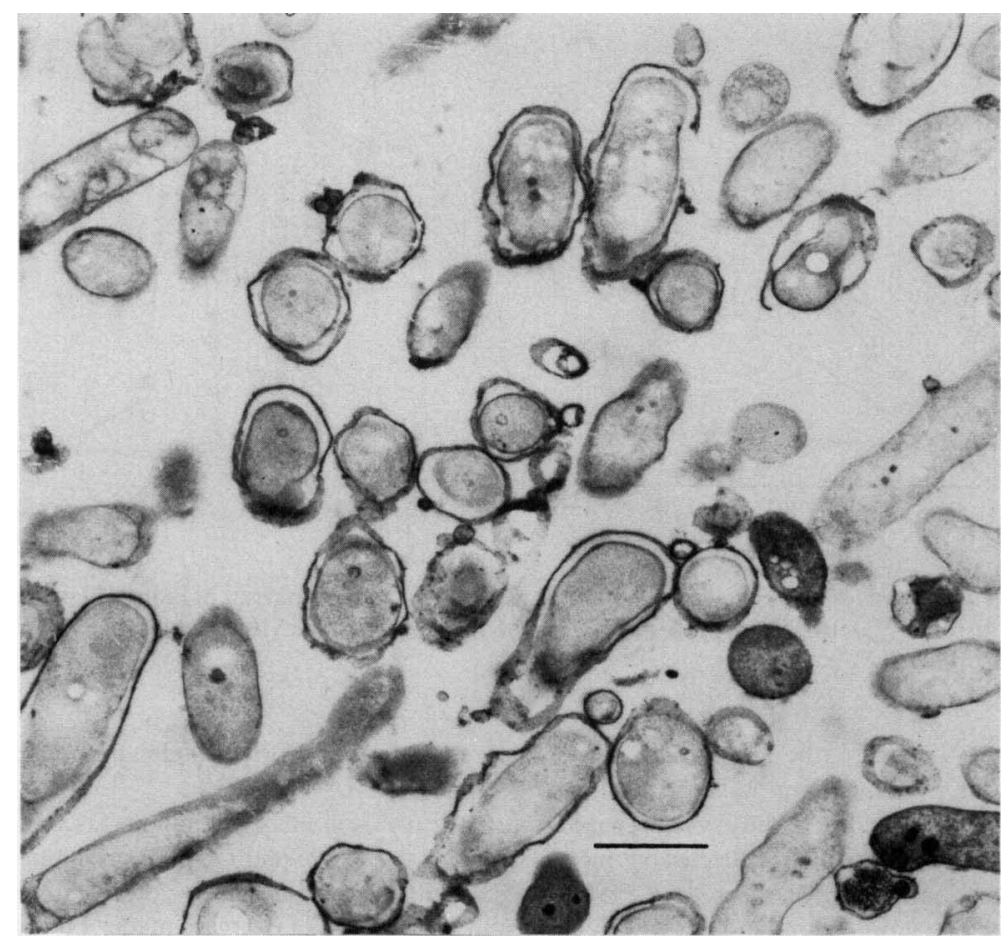

Fig. 2. Electron micrograph of a pelleted bacteroid suspension. The bar marker represents $1 \mu \mathrm{m}$.

protein, this was unexpected. Kennedy et al. (1976) showed that the tetrameric MoFe-protein gave two bands on certain one-dimensional polyacrylamide gels, provided a suitable brand of SDS was used. The MoFe-protein gave two bands upon one-dimensional separation in $10 \%$ and $12 \%$ gels (Fig. $3 a$ ) and the electrophoresis of equal portions of MoFe-protein by one- and twodimensional electrophoresis on the same gel (Fig. 3a) demonstrated that the single spot contained the same amount of protein stained by Coomassie blue as the two bands together. The two bands of the one-dimensional analysis were separated by a distance equal to the diameter of the unresolved spot of MoFe-protein in the two-dimensional gel, and when MoFe-protein was run from an agarose gel containing the denaturants and ampholytes of a standard first dimension gel, a broad band of similar width, unresolved into two sharp components, resulted. This broadening was caused by the urea. When the single spot of denatured MoFe-protein was cut from a two-dimensional gel, treated with SDS and mercaptoethanol at $100{ }^{\circ} \mathrm{C}$, and re-run on a $12 \%$ polyacrylamide-SDS gel the characteristic doublet of MoFe-protein was observed. The MoFe-protein spot could be resolved into a doublet when $8 \%$ gels were used in the second dimension, but this gel concentration was unsuitable for resolving the complement of Rhizobium proteins. Thus the two polypeptide species of the purified MoFe-protein from this Rhizobium strain migrate as a single spot of pI 6.9. Either they have the same or a closely similar isoelectric point naturally or by artifactual modification, or they aggregate or precipitate in the first dimension before reaching their isoelectric points. A fine brown band of pI 6.1 containing iron (detected by plasma emission spectroscopy) separated from preparations of both nitrogenase components upon isoelectric focusing, suggesting that at least some dissociation of metal centres had occurred. The MoFe-protein co-electrophoresed with a major spot in bacteroid lysates (Fig. $3 c$ ). Fe-protein preparations (Fig. $3 b$ ) gave a major spot of pI $5 \cdot 7$, together with a minor, more acidic companion of the same molecular weight. Both spots were also observed in twodimensional gels of bacteroid lysates stained with Coomassie blue. Fe-protein preparations gave a single band on one-dimensional gels (Fig. $3 b$ ). When bacteroid preparations were labelled with 
(a)

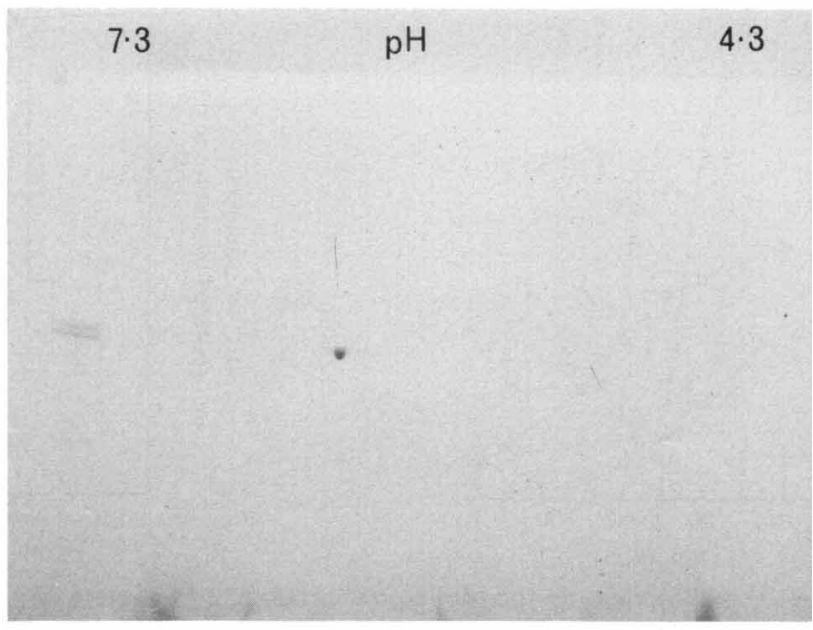

(b)

$7 \cdot 3 \ldots \mathrm{pH}$

(c)

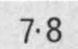

- $\mathrm{pH}$

$4 \cdot 7$

Fig. 3. Localization of nitrogenase proteins on two-dimensional gels. (a) Equal amounts of MoFeprotein electrophoresed two-dimensionally as a spot and one-dimensionally as bands; (b) Fe-protein, with an equal amount in the marker lane (on the left); $(c)$ autoradiograph of ${ }^{35} \mathrm{~S}$-labelled proteins separated by two-dimensional electrophoresis from the lysate of cells labelled at 30-40 min during an oxygen-shock experiment: 1, MoFe-protein; 2, Fe-protein. 

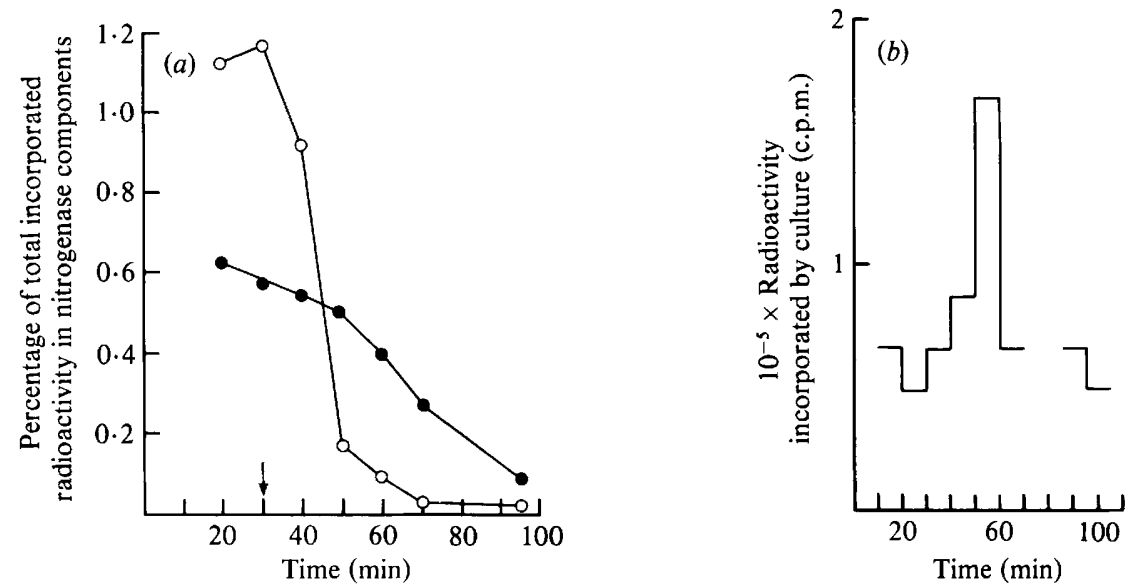

Fig. 4. (a) Amount of radioactivity in the MoFe-protein (O) and Fe-protein (O) spots during an oxygen-shock experiment. The arrow indicates the time when the suspensions were exposed to air. The measurements were made by direct counting. $(b)$. Incorporation of $\left[{ }^{35} S\right]$ methionine during the pulse periods.

$\left[{ }^{35}\right.$ S $]$ methionine, 15 other radioactive spots of the same molecular weight as the MoFe-protein polypeptides were separated on two-dimensional gels, comprising $40 \%$ of the radioactivity in that molecular weight range in samples labelled under $0.2 \mathrm{kPa}$ oxygen. In the autoradiograms analysed for the data below, there were at least two, and up to five, additional minor spots of low radioactivity with the molecular weight of Fe-protein, but with different pI values.

\section{Effect of oxygen shock on the synthesis of nitrogenase proteins}

Suspensions of bacteroids were fed $\left.{ }^{35} \mathrm{~S}\right]$ methionine for $10 \mathrm{~min}$ periods both before and after the cultures were exposed to the air, then cell lysates were prepared and separated on twodimensional gels as described in Methods. One such separation is shown in Fig. 3(c). The kinetic measurements made from such gels and autoradiograms (see Methods) are shown in Fig. 4(a). The rate of incorporation of $\left[{ }^{35} \mathrm{~S}\right]$ methionine was not constant during the various pulse periods following oxygen shock (Fig. 4 b). During the first $30 \mathrm{~min}$ in low oxygen, incorporation remained fairly uniform but increased when the gas phase was changed to air, the time when acetylene reduction ceased. The data have therefore been plotted as the proportion of radioactivity which was incorporated into the $\mathrm{MoFe}$ - and Fe-proteins, with the time points being the terminations of the pulse labellings. The rate of protein synthesis reached a maximum $30 \mathrm{~min}$ after exposure to air and then declined to the initial levels, but despite this, the incorporation into Fe-protein, and eventually into MoFe-protein, was reduced in absolute amount. Approximate calculations indicated that this initial increase in the rate of protein synthesis may have used the energy previously consumed by dinitrogen reduction (Shaw, 1981). Although the Fe-protein spot remained compact in all the samples analysed, the MoFe-protein spot was decidedly streaked in the first dimension in samples labelled after air had been introduced. The Fe-protein companion spot described above had $8 \%$ of the radioactivity of the major Fe-protein spot at the first two time points, and visual observations of the autoradiograms indicated that this radioactivity was gradually lessened after oxygen shock, although this could not be quantified because the radioactivity was too low at later times. The measurements made from gel separations were of net rates of synthesis, so a determination of the rate of degradation was also made to allow an estimate of the actual rate of synthesis of new protein. The turnover of the nitrogenase polypeptides was assessed in a pulse chase experiment. A bacteroid suspension was labelled for $20 \mathrm{~min}$ under $0.2 \mathrm{kPa}$ oxygen. The bacteroids were pelleted, washed, and suspended in fresh aerobic media for a 40 min chase. After this time, the Fe-protein spot contained $98 \% \pm 5 \%$ of the radioactivity of Fe-protein present at the end of the pulse. The net synthesis of Fe-protein 


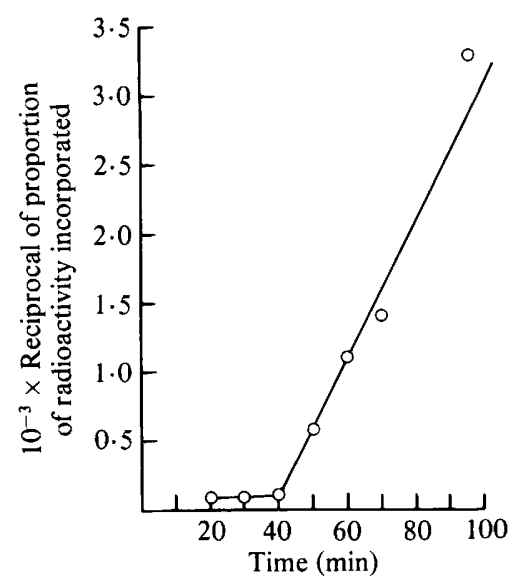

Fig. 5. Reciprocal plot of the labelling data for the Fe-protein, demonstrating second order kinetics.

estimated from the pulse labelling data was therefore closely similar to the actual synthesis rate, with negligible protein degradation occurring over the $10 \mathrm{~min}$ pulse period. There was a markedly different effect of oxygen shock on the labelling kinetics of the two nitrogenase proteins (Fig. 4a). The synthesis of MoFe-protein polypeptides declined more slowly than that for the apo-Fe-protein, but no simple rate model fitted the data. When the reciprocal of the spot radioactivity of the $\mathrm{Fe}$-protein was plotted against time (Fig. 5), a linear relationship was observed; that is, the kinetics were second order with respect to the Fe-protein product (rate = $k$ [product $]^{2}$ ). At the earliest labelling times the Fe-protein spot contained 1.6 times as much radioactivity as the MoFe-protein spot, but this ratio fell after exposure to air.

\section{DISCUSSION}

The nitrogenase components of Rhizobium strain NZP 2257 have been prepared, and their location on two-dimensional gels identified. The Mo-Fe protein polypeptides ran as a single spot under the conditions used, although they were resolved into two bands in one-dimensional gels. The high concentration of urea in the first dimension gels limited resolution in the second dimension. A similar situation appeared to occur with the MoFe-protein from Azotobacter vinelandii (Harker \& Wullstein, 1981) when native protein was electrofocused as a single band. The observed two-dimensional positions of the nitrogenase proteins may not be typical of all Rhizobium strains, because the method is sensitive to single charge variations (O'Farrell, 1975).

The effect of oxygen shock on the synthesis of nitrogenase polypeptides in the Rhizobium bacteroids, determined from two-dimensional analyses, resembled the gradual decline of synthesis observed in $K$. pneumoniae (Eady et al., 1978) rather than the abrupt curtailing of synthesis as in $A$. chroococcum (Robson, 1979). However, the finding that the rates of synthesis of $\mathrm{MoFe}$ - and Fe-protein polypeptides declined differentially following oxygen shock is in contrast to the coordinate effects observed with nitrogenase regulation in $K$. pneumoniae, and has interesting implications for genetic control in Rhizobium. It seems unlikely that this could result from the synthesis of a new protein species co-electrophoresing with the MoFe-protein spot, because minor spots tend to be displaced by major spots of high protein concentration (O'Farrell, 1975). The time course of the repression of MoFe-protein of lupin bacteroids resembled that reported by Scott et al. (1979) for free-living $R$. japonicum, and the time course of synthesis decline of the Fe-protein polypeptide was similar to that reported for all three $K$. pneumoniae nitrogenase polypeptides by Eady et al. (1978). This decline in apo-Fe-protein synthesis appeared to follow second order kinetics, suggesting that some form of the synthesis product, or of a protein linked to it, had a part in the decay kinetics of Fe-protein repression. Dixon et al. (1980) concluded that the products of the nifHDK operon (the structural genes for 
nitrogenase) were unlikely to be involved in oxygen repression in $K$. pneumoniae, which was rather the result of the nifL gene product repressing nifHDK transcription (Hill et al., 1981). If there is generalized regulation of nif genes in Rhizobium, as there is in K. pneumoniae (Hill et al., 1981), a further analysis of the existing data may reveal some additional proteins regulated by oxygen.

During labelling under $0.2 \mathrm{kPa}$ oxygen, there was considerably more radioactivity in the $\mathrm{Fe}-$ protein spot than in the MoFe-protein spot, but as the methionine content of the two proteins is not known, no clear inference can be drawn concerning the amounts of each synthesized. Different ratios of radioactivity in the two proteins have been reported for nitrogenase from pea bacteroids when nodulated plants were fed $\left[{ }^{35}\right.$ S $]$ sulphate (Bisseling et al., 1979). The induction of the two subunits of the MoFe-protein in $R$. japonicum has already been described as coordinate (Scott et al., 1979). Three models would account for the non-coordinate repression observed: (1) there are separate mRNAs for MoFe-protein and Fe-protein because the genes for the MoFeprotein and for the Fe-protein of nitrogenase are not on the same operon; (2) the genes are on the same operon, but the mRNA is degraded differentially; (3) the binding of an inhibitory product suppresses the complete translation of the apo-Fe-protein. The hypotheses must also account for the observed kinetics of the syntheses; the data presented do not permit the elimination of any of the hypotheses chosen. The first model prompts speculation about the location of nitrogenase structural genes which have not yet been fully characterized in any Rhizobium strain (Ruvkun \& Ausubel, 1980; Hennecke, 1981). The second and third hypotheses require a promoter location proximal to an MoFe-protein gene, rather than to the Fe-protein gene, as in $K$. pneumoniae (Dixon et al., 1980).

I would like to thank the Department of Chemistry, Biochemistry and Biophysics, Massey University, for the use of the densitometer, A. Meridith for computer programming, D. Hopcroft and R. Bennett for electron microscopy. I am grateful for helpful discussions with Sugirthamani Shaw, Dr D. B. Scott and Dr W. T. Jones.

\section{REFERENCES}

BERGERSEN, F. J. (1966). Some properties of nitrogenfixing breis prepared from soybean root nodules. Biochimica et biophysica acta 130, 304-312.

Bergersen, F. J. \& TURNeR, G. L. (1975). Leghaemoglobin and the supply of $\mathrm{O}_{2}$ to nitrogen-fixing root nodule bacteroids: studies of an experimental system with no gas phase. Journal of General Microbiology 89, $31-47$.

Bisseling, T., VAN den Bos, R. C. \& VAN KaMmen, A. (1978). The effect of ammonium nitrate on the synthesis of nitrogenase and the concentration of leghemoglobin in pea root nodules induced by Rhizobium leguminosarum. Biochimica et biophysica acta 539, 1-11.

Bisseling, T., van den Bos, R. C., Weststrate, M. W., HakkaART, M. J. J. \& VAN Kammen, A. (1979). Development of the nitrogen-fixing and proteinsynthesizing apparatus of bacteroids in pea root nodules. Biochimica et biophysica acta 562, 515-526.

Bisseling, T., van Staveren, W. \& van Kammen, A. $(1980 a)$. The effect of waterlogging on the synthesis of the nitrogenase components in bacteroids of Rhizobium leguminosarum in root nodules of Pisum sativum. Biochemical and Biophysical Research Communications 93, 687-693.

Bisseling, T., MOEN, A. A., vaN DEN Bos, R. C. \& VAN KAMMEN, A. $(1980 b)$. The sequence of appearance of leghaemoglobin and nitrogenase components I and II in root nodules of Pisum sativum. Journal of General Microbiology 118, 377-381.

Dalton, H. (1980). The cultivation of diazotrophic micro-organisms. In Methods for Evaluating Bio- logical Nitrogen Fixation, pp. 13-64. Edited by F. J. Bergersen. Chichester: John Wiley.

DiXoN, R., EADY, R. R., EsPIN, G., HILl, S., IACCARINO, M., KAHN, D. \& MERrick, M. (1980). Analysis of regulation of Klebsiella pneumoniae nitrogen fixation (nif) gene cluster with gene fusions. Nature, London 286, 128-132.

EAdY, R. R., IssaCK, R., KenNedy, C., Postgate, J. R. \& RATClIFFE, H. D. (1978). Nitrogenase synthesis in Klebsiella pneumoniae: comparison of ammonium and oxygen regulation. Journal of General Microbiology 104, 277-285.

HARKER, A. R. \& WULLSTeIN, L. H. (1981). Resolution of two subunits from the molybdenum-iron protein of Azotobacter vinelandii nitrogenase. Journal of Biological Chemistry 256, 11981-11983.

HENNECKE, H. (1981). Recombinant plasmids carrying nitrogen fixation genes from Rhizobium japonicum. Nature, London 291, 354-355.

Hill, S., KenNedy, C., Kavanagh, E., Goldberg, R. B. \& HANAU, R. (1981). Nitrogen fixation gene (nifL) involved in oxygen regulation of nitrogenase synthesis in K. pneumoniae Nature, London 290, 424-426.

KENNEDY, C., EADY, R. R., KondOROSI, E. \& REKOSH, D. K. (1976). The molybdenum-iron protein of Klebsiella pneumoniae nitrogenase : evidence for nonidentical subunits from peptide 'mapping'. Biochemical Journal 155, 383-389.

LAaNe, C., HaAker, H. \& Veeger, C. (1978). Involvement of the cytoplasmic membrane in nitrogen fixation by Rhizobium leguminosarum bacteroids. European Journal of Biochemistry 87, 147-153. 
LAEMMLI, U. K. (1970). Cleavage of structural proteins during the assembly of the head of bacteriophage T4. Nature, London 227, 680-685.

O'FARRELL, P. H. (1975). High resolution two-dimensional electrophoresis of proteins. Journal of Biological Chemistry 250, 4007-4021.

Roberts, G. P., MACNeIL, T., MACNeIL, D. \& BriLl, W. J. (1978). Regulation and characterization of protein products coded by the nif (nitrogen fixation) genes of Klebsiella pneumoniae. Journal of Bacteriology 136, 267-279.

Robertson, J. G., Warburton, M. P., Lyttleton, P., FordyCE, A. M. \& Bullivant, S. (1978). Membranes in lupin root nodules. II. Preparation and properties of peribacteroid membranes and bacteroid envelope inner membranes from developing lupin nodules. Journal of Cell Science 30, 151-174.

ROBSON, R. L. (1979). $\mathrm{O}_{2}$-repression of nitrogenase synthesis in Azotobacter chroococcum. FEMS Microbiology Letters 5, 259-262.

RuvkuN, G. B. \& AUSUbEL, F. M. (1980). Interspecies homology of nitrogenase genes. Proceedings of the
National Academy of Sciences of the United States of America 77, 191-195.

SCOTT, D. B., HENNECKE, H. \& LiM, S. T. (1979). The biosynthesis of nitrogenase MoFe protein polypeptides in free-living cultures of Rhizobium japonicum. Biochimica et biophysica acta 565, 365-378.

SHAH, V. K. (1980). Isolation of the iron-molybdenum cofactor from nitrogenase. Methods in Enzymology 69, 792-801.

SHAw, B. D. (1981). Lupin bacteroids shocked by oxygen. In Current Perspectives in Nitrogen Fixation, p. 446. Edited by A. H. Gibson \& W. E. Newton. Canberra: Australian Academy of Science.

Surton, W. D. \& Mahoney, P. (1977). Preparation and fractionation of Rhizobium bacteroids by zone sedimentation through sucrose gradients. Plant Physiology 60, 800-802.

Whiting, M. J. \& Dilworth, M. J. (1974). Legume root nodule nitrogenase: purification, properties, and studies on its genetic control. Biochimica et biophysica acta 371, 337-351. 